\title{
PERSAMAAN DERAJAT TERHADAP PEMBAGIAN HAK WARIS ANAK DALAM PUTUSAN MAHKAMAH KONSTITUSI NOMOR 46/PUU-VIII/2010
}

\author{
Atik Abidah \\ Jurusan Syariah STAIN Ponorogo \\ dejureuinmalang@gmail.com
}

\begin{abstract}
Abtract
This research aims to analyze the equality rights of biological children in the decision of the Constitutional Court of the Republic of Indonesia number: 46 / PUU-VIII / 2010 and its legal consequence. This research included in the normative legal research that used a statue approach and case study approach. The research's data analyzed using preskriptive-analytic methode and hermeneutic methode. The Research's results showed that the decision of Constitutional Court of the Republic of Indonesia number: 46 / PUU-VIII / 2010 expand the interpretation of the concept of nasab from legal children towards biological children to achieve the equality and the sense of fairness. This verdict also expand the interpretation of the evidence. The relationship between parents and their childrens can be proved with the aid of science and technology. The similarity of DNA / RNA betwen parents and their childern is the ratio legis ('illat al-hukm) that into consideration the biological children acquire the civil rights, including inheritance rights.
\end{abstract}

Penelitian ini bertujuan menganalisis persamaan hak anak biologis dalam putusan Mahkamah Konstitusi Nomor 46/PUU-VIII/2010 dan akibat hukumnya. Penelitian ini termasuk dalam penelitian hukum normatif dengan pendekatan perundang-undangan (statue approach) dan pendekatan kasus (case study approach). Data penelitian dianalisis dengan metode preskriptif-analitik dan pendekatan interpretatif (hermeneutic). Hasil penelitian menunjukkan bahwa Putusan Mahakamah Konstitusi Nomor 46/PUU-VIII/2010 memperluas penafsiran konsep nasab dari anak yuridis menuju anak biologis demi mewujudkan persamaan derajad dan memenuhi rasa keadilan. Putusan tersebut juga memperluas penafsiran terhadap alat bukti. Hubungan nasab antara orang tua dan anak dapat dibuktikan dengan bantuan ilmu pengetahuan dan teknologi. Persamaan DNA/RNA keduanya merupakan ratio legis ('illat al-hukm) yang menjadi pertimbangan anak biologis mendapatkan hak-hak perdata termasuk hak waris.

Kata Kunci: Persamaan, Waris, Mahkamah Konstitusi

Tahun 2012, lembar sejarah hukum perkawinan di Indonesia diwarnai suasana ketegangan atas putusan mahkamah konstitusi Republik Indonesia (selanjutnya disingkat MK) menyangkut hak waris anak luar kawin. Berdasarkan putusan MK Nomor 46/PUUVIII/2010, pasal 43 ayat (1) Undang-Undang Nomor 1 Tahun 1974 tentang perkawinan $\begin{array}{lll}\text { (selanjutnya disingkat } & \text { UUP) } & 1 \\ & \text { yang }\end{array}$ menyatakan: "Anak yang dilahirkan di luar perkawinan hanya mempunyai hubungan perdata dengan ibunya dan keluarga ibunya,"

\footnotetext{
${ }^{1}$ Menurut putusan MK, pasal 43 ayat (1) UUP tidak memiliki kekuatan hukum mengikat. Dengan putusan tersebut, kedudukan dan hak anak luar kawin termasuk hak anak biologis baik di dalam hukum perkawinan dan hukum kewarisan telah memiliki kedudukan yang sama sebagaimana anak sah (hasil perkawinan yang sah).
} 
dinyatakan bertentangan dengan UndangUndang Dasar Tahun 1945 (selanjutnya disingkat UUD 1945). Dimana tercermin pengakuan hak konstitusional anak di Indonesia dalam konstitusi pasal $28 \mathrm{~B}$ ayat $(2)^{2}$ dan pasal 28D ayat (1) ${ }^{3}$ UUD 1945.

Ketentuan UUD 1945 ini jelas melahirkan norma konstitusi bahwa anak memiliki hak-hak konstitusional $^{4}$ termasuk atas status hukum dan diperlakukan sama dihadapan hukum. Artinya, UUD 1945 mengedepankan norma hukum sebagai bentuk keadilan terhadap siapapun tanpa diskriminasi.

Berdasarkan norma hukum tersebut, secara konstitusional, anak memang berhak memperoleh persamaan derajat dan keadilan hukum, agar tidak merugikan hak-hak konstitusionalnya. Norma tersebut merupakan dasar hukum yang harus dijunjung tinggi bagi kedudukan anak yang memiliki harkat, martabat dan hak-hak asasi sebagai manusia. Akan tetapi, norma hukum tentang hak anak di dalam UUP berkata lain. Menurut UUP, tidak semua anak mendapatkan keistimewaan hakhak sebagaimana tersebut di atas. UUP secara yuridis-normatif, tidak mengakui semua status dan kedudukan anak yang dilahirkan oleh orang tuanya. Pengakuan status dan kedudukan anak sangat bergantung kepada bagaimana proses perkawinan orang tuanya, yaitu perkawinan yang sah. ${ }^{5}$ Menguji keabsahan sebuah perkawinan memang diperlukan legitimasi hukum untuk menetapkan sah atau tidak sahnya perkawinan. Di samping itu, sah menurut agama belum mencerminkan konsep

2 Setiap anak berhak atas kelangsungan hidup, tumbuh, dan berkembang serta berhak atas perlindungan dari kekerasan dan diskriminasi.

3 Setiap orang berhak atas pengakuan, jaminan, perlindungan dan kepastian hukum yang adil serta perlakuan yang sama dihadapan hukum.

4 UU Nomor 24 tahun 2003 tentang Mahkamah Konstitusi menyatakan yang dimaksud "hak konstitusional" adalah hak-hak yang diatur dalam UUD RI 1945.

${ }^{5}$ Norma hukum dalam UUP hanya mengakui anak yang dilahirkan dari perkawinan yang sah menurut UUP. Ketentuan ini sesuai pasal 2 ayat (1) UUP yang menyatakan; Perkawinan adalah sah, apabila dilakukan menurut hukum masing-masing agamanya dan kepercayaannya itu. negara hukum yang syarat dengan asas kepastian hukum. ${ }^{6}$

Kasus pengakuan terhadap anak, belakangan mencuat terkait putusan MK yang mengabulkan uji materi pasal 2 dan pasal 43 ayat (1) UUP terhadap UUD $1945 .^{7}$ Ketentuan pasal-pasal yang diajukan berkaitan dengan pasal-pasal sahnya perkawinan dan kedudukan anak biologis hasil perkawinan sirri, beserta akibat hukumnya. Fenomena ini lalu menjadi topik perbincangan Mahkamah Konstitusi mengabulkan uji materi terhadap pasal-pasal dalam UUP.

Sesaat setelah putusan MK Nomor 46/PUUVIII/2010 diucapkan tanggal 17 Pebruari 2012 langsung mendapat sambutan dan tanggapan yang beragam. Mulai dari kelompok yang mengapresiasi sampai yang mengkhawatirkan implikasi putusan tersebut. Dari berbagai tanggapan atas putusan ini mengingatkan pada era pluralisme hukum keluarga di Indonesia masa lalu. ${ }^{8}$

Persoalan yang muncul atas putusan MK bahwa ternyata anak biologis yang dihasilkan dari perkawinan yang tidak sah dalam hal ini perkawinan sirri, yang memiliki kerawanan dalam pelaksanaan perkawinan, memiliki hak yang sama sebagaimana anak hasil perkawinan

\footnotetext{
${ }^{6}$ Perkawinan harus dicatat yaitu dengan meregristasikan seluruh peristiwa perkawinan di dalam akta perkawinan, di bawah pengawasan pegawai pencatatan perkawinan, sehingga perkawinan menjadi sah secara yuridis. Sebagaimana pernyataan pasal 2 ayat (2) UUP; Tiap-tiap perkawinan dicatat menurut perundang-undangan yang berlaku.

${ }^{7}$ Permohonan uji materi UUP terhadap UUD 1945 diajukan oleh $\mathrm{Hj}$. Aisyah Mochtar alias Machica binti $\mathrm{H}$. Mochtar Ibrahim bersama Muhammad Iqbal Ramadhan bin Moerdiono, pada tanggal 14 juni 2010.

8 Sebelum lahir Undang-Undang Perkawinan, masyarakat Indonesia tunduk pada hukum perkawinan yang beraneka ragam, berdasarkan gologan dan daerah. Keberhasilan melakukan unifikasi hukum perkawinan merupakan babak baru, meskipun melalui perdebatan panjang. Perdebatan ini tidak hanya terjadi di parlemen, namun melebar ke arus bawah yang kesemuanya bermuara pada keinginan penyususnan materi Rancangan Undang-Undang yang sejalan dengan aspirasi hukum masing-masing. Akhirnya, pada tahun 1974 bangsa Indonesia patut bersyukur telah memiliki Undang-Undang Perkawinan yang berlaku secara nasional bagi semua warga Negara. Lihat, Abdul Manan, Aneka Masalah Hukum Perdata Islam di Indonesia, (Jakarta: Kencana Prenada Media Group, 2008), hlm. 36.
} 
yang sah, ternyata memunculkan hukum baru dalam konfigurasi politik hukum di Indonesia. Ketentuan ini tertuang dalam putusan MK yang menyatakan bahwa:

\section{Anak yang lahir di luar perkawinan hanya mempunyai hubungan perdata dengan ibunya dan keluarga ibunya, serta dengan laki-laki sebagai ayahnya yang dapat dibuktikan berdasarkan ilmu pengetahuan dan teknologi dan/atau bukti lain yang menurut hukum ada hubungan darah, termasuk hubungan perdata dengan keluarga ayahnya.}

Putusan ini menuai berbagai problematika di Indonesia, baik normatif maupun sosial, juga pertentangan asas dan norma (conflict of norm) dengan prinsip kedudukan anak dalam hukum
Berdasarkan isu hukum di atas, maka putusan MK yang unik dan membawa akibat hukum besar terhadap fenomena hukum perkawinan, hukum kedudukan anak biologis dan hukum kewarisan, memang masih menyimpan persoalan krusial terutama di ranah normatif. Sehingga, kajian normatif tentang pergeseran asas persamaan derajat dan asas keadilan terhadap pembagian hak waris anak biologis, akibat hukum putusan MK tentang kedudukan hak anak biologis masih aktual dan sangat menarik untuk diteliti lebih komprehensif khususnya pergeseran asas persamaan derajat dan asas keadilan terhadap pembagian hak waris anak dalam putusan Mahkamah Konstitusi Nomor 46/PUUVIII/2010 telah mewujudkan rasa keadilan terhadap pembagian hak waris anak. Apa

Bagan 1

Kerangka Penelitian

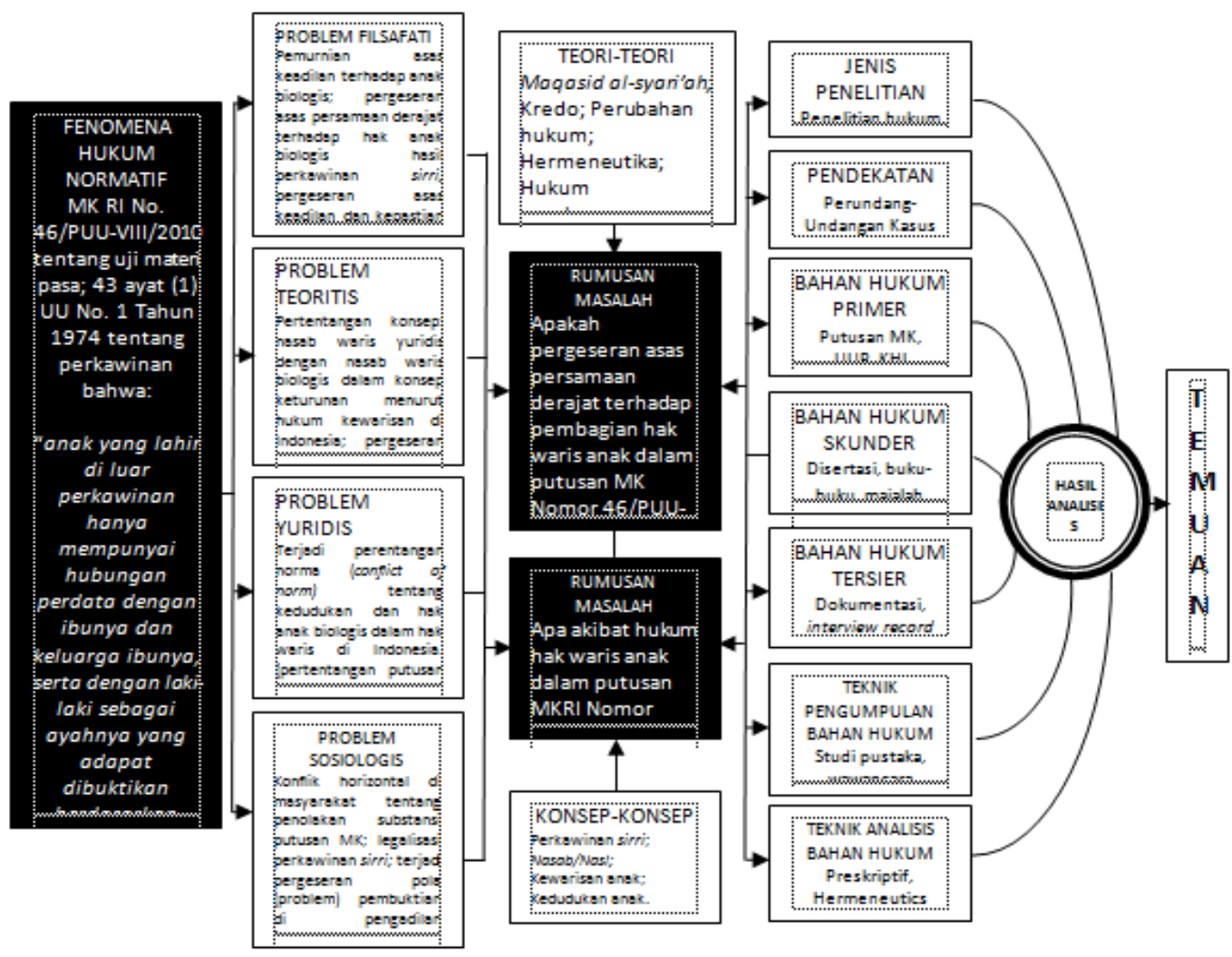

kewarisan Islam yang tertuang dalam syari'at Islam serta kedudukan hukum anak dalam konstruksi hukum keluarga yang berlaku di Indonesia terutama yang terdapat dalam pasal 41 UUP. Selain itu juga menimbulkan problematika filsafati, teoritis, yuridis dan sosiologis. akibat hukum hak waris anak sesudah putusan Mahkamah Konstitusi RI Nomor 46/PUUVIII/2010

\section{Metode Penelitian}

Penelitian ini adalah penelitian hukum normatif, yaitu penelitian yang akan mengkaji peraturan perundang-undangan dalam suatu tata yang koheren tentang hukum sebagai 
norma positif yang berlaku pada suatu waktu sebagai produk suatu kekuasaan tertentu. ${ }^{9}$ Sedangkan pendekatan yang digunakan adalah pertama, pendekatan perundang-undangan (statue approach), ${ }^{10}$ yaitu dengan melakukan pengumpulan dan mengkaji teks pasal demi pasal dalam putusan MK RI Nomor 46/PUUVIII/2010 tanggal 17 Pebruari 2012, UU Nomor 1 Tahun 1974 tentang perkawinan, instruksi Presiden Nomor 1 Tahun 1991 tentang kompilasi hukum Islam dan UUD 1945. Kedua, pendekatan kasus, yang diterapkan untuk mencerna berbagai pandangan dan putusan hukum yang berkaitan dengan hak anak luar kawin serta kasus Machica Mochtar. Adapun jenis penelitian ini juga termasuk dalam penelitian Preskriptif. ${ }^{11}$

Sesuai dengan sifat penelitian hukum normatif, maka kajian pokok penelitian dilakukan dengan studi bahan hukum primer ${ }^{12}$, skunder $^{13}$ dan tersier ${ }^{14}$. Kemudian teknik pengumpulan bahan jukum tersebut dilakukan dengan menggunakan metode studi pustaka dan jelajah risalah putusan dan peraturan perundang-undangan terkait tema penelitian. Sekaligus melacak bahan pustaka berupa bukubuku tentang hukum perkawinan dan kewarisan.

\footnotetext{
${ }^{9}$ Soetandyo Wignyosubroto, Sebuah Pengantar ke Arah Perbincangan tentang Pembinaan Penelitian Hukum dalam Pembangunan Jangka Panjang Tahap II, (Jakarta: BPHN Departemen Kehakiman, 1995), hlm. 5.

10 Bambang Waluyo, Penelitian Hukum dalam Praktek, (Jakarta: Sinar Grafika, 2002), hlm. 17.

11 Peter Mahmud Marzuki, Penelitian hukum, (Jakarta: Kencana, 2006), hlm. 96.

12 Terdiri atas semua bahan peraturan perundangundangan di Indonesia terkait dengan hukum kewarisan dan perkawinan, yaitu putusan Mahkamah Konstitusi RI Nomor 46/PUU-VIII/2010 tanggal 17 Pebruari 2012, UU Nomor 1 Tahun 1974 tentang perkawinan, instruksi Presiden Nomor 1 Tahun 1991 tentang kompilasi hukum Islam.

${ }^{13}$ Terdiri atas semua publikasi hukum terkait hukum kewarisan dan perwakinan yang bukan merupakan dokumen resmi meliputi peraturan perundang-undangan tentang kewarisan dan perkawinan yang telah dicabut atau telah diuji materi oleh MK, buku-buku literatur, tulisan-tulisan, baik dalam jurnal hukum maupun koran, situs, website.

14 Yaitu bahan hukum penunjang yang mencakup bahan-bahan yang memberi petunjuk terhadap hukum primer dan skunder, yakni kamus umum bahasa Indonesia dan kamus hukum yang dipergunakan untuk menerjemahkan terminologi-terminologi asing.
}

Teknik analisis dalam mengola bahan hukum tersebut adalah melalui metode analisis secara preskriptif-analitik. Hukum dalam status preskriptif, manakala hukum termasuk putusan hakim MK akan menjadi prinsip kokoh yang membuat "benda-benda" (subyek dan obyek hukum) harus tunduk dan patuh terhadap hukum. ${ }^{15}$ Selain itu juga dianalisis dengan pendekatan interpretatif (hermeneutic). Interpretasi teks dan konteks digunakan dalam rangka untuk memahami teks-teks dalam bahan hukum primer, sehingga didapatkan pemahaman yang tepat terhadap permasalahan yang diteliti sesuai dengan situasi dan kondisi berlakunya hukum baru.

\section{Kerangka Teoritik}

\section{Teori Maqashid Syari'ah dan Maslahah}

Secara etimologis, Maqashid Syari'ah adalah tujuan hukum. Yaitu tujuan hukum Islam yang mewujudkan kemaslahatan, kebaikan, ketenteraman dan kesejahteraan. Sedangkan maslahah adalah kemanfaatan dan kebaikan.

Sepanjang sejarah hukum Islam, teori maslahat telah melalui reformulasi dinamika pemikiran para ulama ahli ushul. ${ }^{16}$ Diantaranya adalah Imam Al Ghazali, yang mengungkapkan makna genuine teori maslahah adalah mewujudkan kemanfaatan dan menyingkirkan kemudharatan. $^{17}$ Al-Ghazali mengkategori maslahah dalam 3 tingkat yaitu daruriyyat (kebutuhan primer), hajiyyat (kebutuhan skunder) dan tahsiniyyat (kebutuhan tersier). Lalu tingkat kebutuhan tersebut disempurnakan dengan perumusan objek 3 tingkat maslahah yang dikenal dengan ushul al-khamsah (5 prinsip dasar jaminan). ${ }^{18}$ Kemudian disempurnakan lagi oleh Shihab al-Din dengan

\footnotetext{
${ }^{15}$ Lorens Bagus, Kamus Filsafat, (Jakarta: Gramedia Pustaka Utama, 2000), hlm. 885.

${ }^{16}$ Asnawi, Teori Maslahah dan Relevansinya dengan Perundang-Undangan Pidana Khusus di Indonesia, (Jakarta: Badan Litbang dan Diklat Kemenag. RI, 2010), hlm. 35 .

17 Abu Hamid Muhammad bin Muhammad AlGhazali, Al-Mustasyfa min Ilmi al-Ushul, Tahqiq wa Tahliq Muhammad Sulaiman al-Asyqar, (Beirut: Mu'assasat al-Risalah, 1997), Juz I, hlm. 416-417.

${ }^{18}$ Hifdzu al-din, hifdzu al-nafs, hifdzu al- 'aql, hifdzu al-nasl dan hifdzu al-mal,
} 
menambahkan hifdzu al- ird (kehormatan). ${ }^{19}$ Kemaslahatan adalah tujuan dari aturan-aturan Islam. Imam Al-Ghazali menyebutnya dengan istilah maqashid al-syari'ah. ${ }^{20}$

\section{Teori Kredo}

Menurut teori kredo, seseorang yang menganut suatu keyakinan atau agama diharuskan tunduk dan patuh kepada hukum agama yang dianutnya. Landasan filsafati lahirnya teori kredo adalah kesaksian seseorang untuk menjadi muslim dengan mengucapkan kalimat syahadah sebagai konsekwensi logis dari pengucapan kredonya. ${ }^{21}$ Dalam ranah kajian filsafat ilmu hukum, kredo merupakan turunan dari prinsip ketuhanan, yang mana prinsip setiap muslim diharuskan tunduk dan patuh kepada apa-apa yang diperintahkan Allah dalam Al-Qur'an dan Rasul dalam Sunnahnya.

Teori lain yang mendukung teori kredo adalah teori autoritas hukum yang diperkenalkan oleh H.A.R Gibb. ${ }^{22}$ Ia mengatakan bahwa seseorang harus tunduk kepada hukum agama yang dianutnya. Filosofi pernyataan tersebut menunjukkan bahwa seseorang yang mengakui dirinya sebagai muslim mempunyai kewajiban untuk tunduk, taat dan patuh kepada hukum agama.

\section{Teori Perubahan hukum}

Teori perubahan hukum dikemukakan oleh Ibnu Qayyim al-Jauziyyah yaitu "taghayyuru al-ahkami bitaghayyuri al-azmani wa alamkinati wa al-ahwali". 23 Maksudnya adalah perubahan hukum dipengaruhi oleh waktu, tempat dan keadaan. Pada dasarnya prinsip

${ }^{19}$ Shihab al-Din al-Qarafy, Syarah Tanqih al-Fushul fi Ihtisar al-Mahsul fi Usul, (Mesir: Maktabah alKhairiyah, tth), hlm. 89.

20 Abu Hamid Muhammad bin Muhammad AlGhazali, Al-Mustasyfa,,, hlm. 281.

${ }^{21}$ Juhaya S. Praja, Teori-Teori Hukum, Suatu Telaah Perbandingan dengan Pendekatan Filsafat, (Bandung: Pustaka Setia, 2009), hlm. 107.

22 H.A.R. Gibb, The Modern Trends of Islam, (Jakarta: CV. Rajawali Press, 1991), hlm. 114.

${ }^{23}$ Ibnu Qayyim Al-Jauziyyah, I'lam al-Muwaqi'in 'an Rabb al-'Alamin, Juz. III, (Beirut: Dar al-Jiil, 1973). Fathurrahman Djamil, Metode Ijtihad Majlis tarjih Muhammadiyah (Cet. I, Jakarta: Logos Publishing House, 1995), hlm. 28. Kurniati, "Pemikiran Ibnu Qayyim Al-Zauziyyah tentang Pengaruh Perubahan Sosial", Program Pascasarjana UIN Alauddin Makassar dalam Jurnal Al-Risalah, Volume 10, 1 mei 2010, hlm. 111. pemikiran teori ini senantiasa mengacu kepada kemaslahatan manusia, dan kemaslahatan manusia banyak terkait dengan tempat, zaman dan keadaan lingkungannya.

Seperti itulah aplikasi prinsip-prinsip hukum Islam di masyarakat yang hendaknya koheren dengan perubahan hukum Islam sesuai dengan situasi dan kondisi dalam masyarakat itu sendiri. Logika semacam ini sesuai dengan kaidah hukum Islam yang menyatakan "berubahnya suatu hukum hendaknya disesuaikan dengan situasi, kondisi, waktu dan tempatnya". ${ }^{24}$

\section{Teori Hermeneutika Hukum}

Teori hermeneutika hukum terbatas pada teori gerak ganda (double movement) yang dikemukakan Fazlur Rahman dan teori limit yang dikemukakan Syahrour.

Ruang lingkup hermeneutika dapat dikategorikan kepada penafsiran kitab suci, sebagai pemahaman linguistik, sebagai fondasi dari geisteswissencchaft, fenomenologi dasein dan pemahaman eksistensial serta sebagai sistem interpretasi. ${ }^{25}$ Untuk menemukan makna anak dan untuk melihat secara langsung penerapan norma hukum tentang kedudukan anak yang muncul pada konteks sosial.

Adapun teori limit atau batas (nadzariyah al hudud) Syahrour menegaskan bahwa teori limit merupakan salah satu pendekatan dalam berijtihad, yang digunakan mengkaji ayat-ayat yang berisi pesan hukum dalam Al-Qur'an. Hudud atau limit tersebut mengacu pada pengertian "batas-batas ketentuan Allah yang tidak boleh dilanggar, tapi di dalamnya terdapat wilayah ijtihad yang bersifat dinamis, fleksibel, dan elastis". ${ }^{26}$

${ }^{24}$ Ibnu Qayyim Al-Jauziyyah, I'lam al-Muwaqi'in, (Kairo: Maktabat al-Kulliyyat al-Azhariyyah, 1980), vol. III, hlm. 3. Lihat juga Mukhlis Usman, Kaidah-Kaidah Ushuliyah dan Fiqhiyyah, (Jakarta: Gema Insani Press, 2000), hlm. 14.

25 Jazim Hamidi, Hermeneutika Hukum: Sejarah Filsafat dan Metode Tafsir, (Malang: UB Press, 2011), hlm. 82-87.

26 Ide teori batas Syahrour diakui sebagai hasil refleksinya sebagai ilmuan fisika. Digambarkan sebagai berikut "perintah Tuhan yang diungkapkan dalam AlQur'an dan Sunnah mengatur ketentuan-ketentuan yang merupakan batas terendah (al-had al-adna) dan batas tertinggi (al-had al-a'la) bagi perbuatan manusia. Batas terendah mewakili ketetapan hukum minimun dalam sebuah kasus hukum dan batas tertinggi mewakili batas 


\section{Teori Perundang-Undangan}

T. Koopmans memberikan pengertian teori perundang-undangan sebagai sekumpulan pemahaman-pemahaman, titik-titik tolak, dan asas-asas yang saling berkaitan memungkinkan munculnya pemahaman yang lebih baik terhadap sesuatu perundang-undangan yang coba di dalami. ${ }^{27}$ Sedangkan A. Hamid S. Attamimi memberikan pengertian teori perundang-undangan adalah cabang atau sisi pemahaman yang bersifat mendasar di bidang perundang-undangan.

Unsur-unsur perundang-undangan meliputi; pertama, dibuat dalam bentuk tertulis sebagai kaidah hukum; kedua, dibuat oleh organ atau badan yang berwenang; dan ketiga, mengikat secara umum. Lalu terkait aspek-aspek penting mengenai teori perundang-undangan yaitu, pertama, asas hukum; kedua, norma hukum; dan ketiga, asas-asas pembentukan peraturan perundang-undangan.

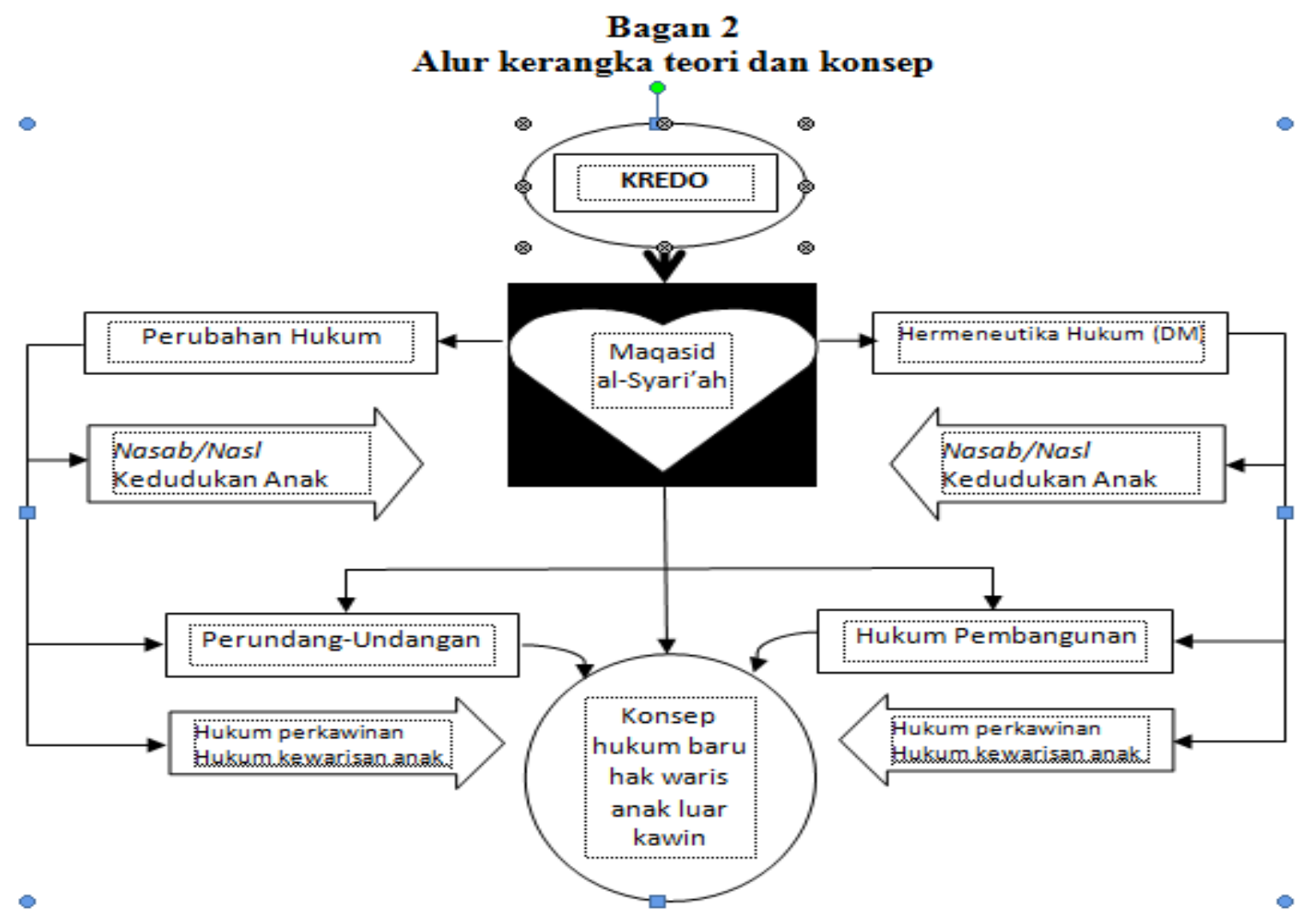

lain dari ilmu perundang-undangan, yang lebih bersifat kognitif dan berorientasi kepada mengusahakan kejelasan dan kejernihan

maksimumnya. Tidak ada suatu bentuk hukum yang lebih rendah dari batas minimum atau lebih tinggi dari batas maksimum. Ketika batas-batas ini dijadikan panduan, kepastian hukum akan terjamin sesuai dengan ukuran kesalahan yang dilakukan. Artinya ketika batasbatas dilampaui maka hukuman harus dijatuhkan menurut proorsi pelanggaran yang terjadi. Jadi manusia dapat melakukan gerak dinamis di dalam batas-batas yang telah ditentukan. Tsuroyah Kiswati, Rekonstruksi Metodologis Wacana Keagamaan Muhammad Syahrour, dalam jurnal Islam ica, Vol. 4, Nomor 2, Maret 2010, hlm. 281.

${ }^{27} \mathrm{~T}$. Koopmans, Vergelijkend Publikerecht, (Deventer-Kiuwer, 1986), hlm. 3. Dikutip oleh Lauddin Masruni, Hukum dan Kebijakan Perpajakan di Indonesia, (Yogyakarta: UII Press, 2006), hlm. 21.

\section{Teori Hukum Pembangunan}

Mochtar Kusumaatmadja mencetuskan teori hukum pembangunan adalah salah satu perkembangan teori hukum di Indonesia yang banyak mengundang perhatian dari pakar dan masyarakat. $^{28}$ Ada beberapa argumentasi

\footnotetext{
${ }^{28}$ Istilah lain sebutan teori ini adalah teori pembangunan hukum dan konsep pembangunan hukum. Pembangunan hukum lebih ditujukan untuk memantapkan dan mengamankan pelaksanaan pembangunan dan hasil-hasilnya, menciptakan kondisi masyarakat yang membuat anggota masyarakat dapat menikmati iklim kepastian dan ketertiban hukum, lebih mengarahkan pembangunan untuk mencapai kemakmuran yang adil dan merata, menumbuhkembangkan disiplin dan rasa tanggungjawab sosial setiap anggota masyarakat, mengayomi masyarakat, memberi rasa aman dan tentram,
} 
krusial mengapa teori hukum pembangunan mengundang banyak atensi, yang dapat dijabarkan secara global sebagai berikut; ${ }^{29}$ pertama, teori hukum pembangunan sampai saat ini adalah teori yang eksis di Indonesia karena diciptakan oleh orang Indonesia. Kedua, secara dimensional teori ini memakai kerangka acuan pada pandangan hidup (way of live) masyarakat dan bangsa Indonesia berdasarkan asas pancasila yang bersifat kekeluargaan. Ketiga, pada dasarnya teori ini memberikan dasar fungsi hukum sebagai "sarana pembaharuan masyarakat" (law as a tool social engineering) dan hukum sebagai suatu sistem yang sangat diperlukan bagi bangsa Indonesia sebagai negara yang sedang berkembang.

Inti dari teori hukum pembangunan yang dikemukakan oleh Mochtar Kusumaatmadja bahwa, tidak hanya kaidah hukum atau peraturan hukum yang dapat berperan, tetapi lembaga dan proses hukum juga mempunyai andil yang besar dalam menunjang tujuan yang ingin dicapai dalam pembangunan. Dengan kata lain hukum secara luas tidak hanya kaidah tetapi juga institusi dan proses. ${ }^{30}$

\section{Pergeseran Asas Persamaan Derajat Hak Anak Terhadap Pembagian Hak Waris Anak dalam Putusan Mahkamah Konstitusi Nomor 46/PUU-VIII/2010}

Putusan yang dimaksud dalam konteks hukum Indonesia adalah putusan sebagai putusan hakim atau pengadilan. Meskipun demikian, terdapat perbedaan pengertian putusan antara hukum perdata dan pidana. Konsep dan sistematika putusan MK pun dalam beberapa dekade telah terjadi perbedaan. $^{31}$

menciptakan iklim yang mendorong kreativitas, partisipasi masyarakat dan mendukung stabilitas nasional yang dinamis.

${ }^{29}$ Lilik Mulyadi, "Teori Hukum Pembangunan Prof. Dr. Mochtar Kusumaatmadja, S.H., LL.M, sebuah kajian deskriptif analisis," dalam www.hukumonline.com, diundunh tanggal 16 februari 2012.

${ }^{30}$ Mochtar Kusumaatmadja, Fungsi Hukum dalam Pembangunan, (Jakarta: Bina Cipta. 1976), hlm. 7

${ }^{31}$ Sejak tahun 2003 hakim konstitusi periode pertama (2003-2008) menerapkan sistematika putusan MK yang terdiri dari; 1) identitas pemohon, 2) duduk perkara, 3) pertimbangan hukum, 4) pendapat berbeda, 5) amar putusan, 6) tanda tangan majlis hakim dan 7) tanda tangan panitera. Sistematika ini ternyata menyulitkan masyarakat umum untuk membaca putusan MK. Oleh
Putusan yang dijatuhkan oleh majlis hakim konstitusi terhadap suatu Undang-Undang akan membawa akibat hukum tidak hanya bagi pihak atau individu yang mengajukan perkara tersebut ke mahkamah konstitusi, tetapi juga orang lain, lembaga negara dan aparatur pemerintah serta masyarakat pada umumnya. Inilah mengapa perkara pengujian UndangUndang di Mahkamah Konstitusi tidak dalam bentuk gugatan, melainkan permohonan. Subjek hukum yang mengajukan perkara disebut pemohon, bukan penggugat. Para pencari keadilan (justiciabellen) harus memiliki kedudukan hukum (legal standing) ${ }^{32}$ yang sah agar permohonannya dapat diproses oleh majlis hakim konstitusi. Persyaratan legal standing mencakup syarat formil dan syarat materiil.

Karakter putusan dalam pengujian norma antara Undang-Undang dengan UndangUndang Dasar, yang menarik untuk diapresiasi dari putusan MK adalah adanya putusan berdimensi penemuan hukum (legal rechtsvinding) yang meliputi 3 jenis karakter. ${ }^{33}$ Selain itu, dinamika putusan-putusan Mahkamah Konstitusi berkarakter progresif dalam berbagai kasus, dapat dilihat dalam karakteritik metodologis penemuan hukum melalui penafsiran argumentum a contrario (kontekstual), tekstual/gramatikal, dan teleologis/ sosiologis. ${ }^{34}$

karenanya, pada tahun 2004 dilakukan revisi, terutama yang berkaitan dengan penempatan pendapat berbeda dari hakim konstitusi. Pada tahun 2005 sistematika terus disempurnakan dengan mengubah lagi penempatan pendapat berbeda yang diletakkan setelah tanda tangan majlis hakim konstitusi.

${ }^{32}$ Menurut Harjono, legal standing adalah keadaan dimana seseorang atau suatu pihak ditentukan memenuhi syarat dan oleh karena itu mempunyai hak untuk mengajukan permohonan penyelesaian perselisihan atau sengketa atau perkara di depan mahkamah konstitusi. Dengan demikian, pemohon harus mampu membuktikan keabsahan legal standing-nya sehingga permohonnanya dapat diperiksa, diadili, dan diputus oleh Mahkamah Konstitusi.

33 Pertama, jenis putusan yang berani dalam mengenyampingkan ketentuan Undang-Undang; kedua, jenis putusan yang menunda tidak mengikatnya UndangUndang; dan ketiga, jenis putusan konstitusional bersyarat.

${ }^{34}$ Disarikan dalam Jurnal Konstitusi oleh Pusat Studi Konstitusi FH Andalas, "Perkembangan Pengujian Perundang-undangan di Mahkamah Konstitusi," Jurnal 
Atik Abidah, Persamaan Derajad Terhadap Pembagian... | 183

Penemuan hukum oleh hakim dapat dipandang sebagai perwujudan dari hukum progresif. Gagasan sentral dari penemuan hukum yang progresif yaitu hukum dan peradilan diposisikan sebagai alat untuk melakukan perubahan sosial. Tujuan puncak hukum yaitu untuk manusia, bukan sebaliknya. Oleh karena itu, penemuan hukum progresif yang dilakukan oleh hakim tidak boleh melepaskan diri dari faktor hukum, kemanusiaan dan moralitas. ${ }^{35}$ Perwujudan hukum progresif ketika hakim melakukan tugas yustisialnya yang terutama dituangkan melalui putusan-putusannya. Dengan demikian, penemuan hukum oleh hakim akan memberi manfaat positif bagi kehidupan manusia.

Pembahasan dalam konteks studi tentang putusan mahkamah konstitusi ini, hakim konstitusi juga melakukan penemuan hukum ketika melakukan penafsiran atas UUD 1945 atau peraturan perundang-undangan ${ }^{36}$ terkait karena tidak mengatur secara jelas mengenai perkara pengujian konstitusional yang sedang ditangani oleh hakim konstitusi. Penemuan hukum itu juga dilakukan oleh hakim konstitusi atas dasar lebih mengedepankan aspek keadilan hukum dan kemanfaatan hukum dari pada kepastian hukum. Untuk melakukan penemuan hukum ini, hakim konstitusi melakukan penafsiran secara progresif atau ekstensif yang boleh jadi melampaui batas kewenangannya (ultra petita).

Kedudukan pertimbangan hukum dalam putusan sangat penting. Bahkan dapat dikatakan sebagai inti persoalan yuridis (illat al-hukm-ratio legis) dari sebuah putusan hakim. Suatu pertimbangan hukum dalam putusan hakim dipandang cukup apabila memenuhi syarat minimal pertimbangan sebagai berikut: pertama, pertimbangan telah ditinjau dalam perspektif hukum dan perundang-undangan. Kedua, pertimbangan demi mewujudkan keadilan, dan ketiga,

Konstitusi, Volume 7 Nomor 6, Desember 2010, hlm. 187-188

35 Munafrizal Manan, Penemuan Hukum oleh Mahkamah Konstitusi, (Bandung: Mandar Maju, 2012), hlm. 23.

${ }^{36}$ Tegasnya, penafsiran konstitusi adalah penafsiran yang digunakan sebagai suatu metode penemuan hukum berdasarkan konstitusi atau Undang-Undang Dasar yang digunakan atau berkembang dalam praktik peradilan Mahkamah Konstitusi. pertimbangan

untuk

mewujudkan

kemaslahatan.

Pertimbangan hukum dalam putusan merupakan posisi yang sangat menentukan produk sebuah hukum. Melalui pertimbangan hukum akan terlihat kualitas sebuah putusan. Selanjutnya pertimbangan hendaknya berdasar atas dan demi mewujudkan keadilan. Sama halnya dengan keadilan, pertimbangan hukum hendaknya berdasarkan spirit yang mewujudkan kemaslahatan. Putusan hakim harus mendatangkan maslahat dan mencegah madlarat sebagaimana kaidah jalbu almanfa'ah aw daf'u al-madharah. ${ }^{37}$ Langkah untuk mengetahui mana yang maslahat dan mana yang madlarat bergantung pada kedalaman menggali dan kecerdasan Hakim melalui kemampuan analisa yang cermat, obyektif dan holistik termasuk wawasannya tentang 'urf atau tradisi, meskipun hasil kajiannya terbatas pada kemaslahatan duniawi.

Berkaitan dengan putusan MK tentang hak waris anak luar kawin bahwa pertimbangan hukum yang menjadi dasar adanya "perlakuan" istimewa terhadap anak luar kawin adalah semata sebagai bentuk perlindungan terhadap anak itu sendiri. Sebab objek fokus kajian dalam putusan MK tidak lain adalah seorang manusia yaitu anak-anak. Terminologi anak menjadi penting untuk menggali sejauhmana hakim MK memutuskan status seorang anak.

Keberadaan seorang anak tidak bisa dilepaskan dari lingkungan keluarga yang membesarkannya. Begitupun dalam ruang lingkup hukum, seorang anak selalu akan terpaut erat dengan persoalan tentang hukum keluarga. Hukum kekeluargaan meliputi beberapa persoalan antara lain hubungan anak dengan orang tuanya, hubungan anak dengan keluarga, pemeliharaan anak piatu dan mengadopsi anak. ${ }^{38}$

Persoalan mengenai kedudukan anak di luar perkawinan yaitu berawal dari munculnya kerugian konstitusional berupa hak anak dari

37 Artinya, menarik atau mewujudkan kemanfaatan/kemaslahatan atau menyingkirkan/ menghindari kemudharatan. Kaidah ini merupakan makna genuine yang dicetuskan oleh Al-Ghazali.

38 Merini, "Tinjauan yuridis terhadap kedudukan anak di luar perkawinan pasca putusan MK Nomor 46/PUU-VIII/2010," STIH Palangka Raya, 2012, hlm. 45. 
Hj. Aisyah Mochtar alias Machicha Mochtar binti H. Mocthar Ibrahim yaitu Muhammad Iqbal Ramadhan bin Moerdiono. Para pemohon kemudian mengajukan uji materiil atas dasar adanya hak konstitusional sebagai warga negara yang dianggap telah dilanggar oleh adanya ketentuan pasal 2 ayat (2) dan pasal 43 ayat (1) Undang-Undang Nomor 1 tahun 1974 tentang perkawinan yang telah bertentangan dengan ketentuan pasal 28B ayat (1) dan (2) dan pasal 28D ayat (1) UUD 1945, hal ini dapat dilihat dari dalil-dalil pemohon. ${ }^{39}$

Akan tetapi, karena perkawinan tersebut tidak dicatatkan di kantor pencatat perkawinan yang dalam hal ini di Kantor Urusan Agama (KUA), maka pemohon tidak mendapatkan haknya dihadapan hukum dengan adanya ketentuan pasal 2 ayat (2) dan pasal 43 ayat (1) UU Nomor 1 tahun 1974 tentang perkawinan. Secara materiil perkawinan tersebut sudah tidak dipersoalkan karena pihak pemohon telah menyampaikan bukti-bukti, namun karena kedua belah pihak tidak mendaftarkan perkawinannya sesuai dengan pasal 2 ayat (2) UUP, maka secara hukum formil perkawinan itu belum diakui keberadaannya, sehingga anak yang dilahirkan digolongkan sebagai anak di luar kawin dalam pengertian secara legal formal. Secara singkat, legitimasi hukum yang menyatakan bahwa Muhammad Iqbal adalah anak di luar kawin inilah yang menimbulkan akibat hukum Muhammad Iqbal tidak berhak atas warisan Alm. Moerdiono. Tetapi dengan munculnya putusan MK Nomor 46/UUPVIII/2010, legitimasi hukum yang menyatakan Muhammad Iqbal adalah anak diluar kawin semuanya telah terhapus. Dengan demikian, secara normatif hak-hak Muhammad Iqbal terutama hak materiil, saat ini mendapatkan legitimasi yang kuat berdasarkan putusan tersebut.

39 Materi pokok permohonan Machicha Mochtar adalah bahwa pada tanggal 20 desember 1993 di Jakarta telah berlangsung pernikahan antara pemohon (Machicha Mochtar) dengan seorang laki-laki bernama Drs. Moerdiono, dengan wali nikah Alm. H. Mochtar Ibrahim, disaksikan oleh 2 (dua) orang saksi, masingmasing bernama Alm. KH. M. Yusuf Usman dan Risman, dengan mahar seperangkat alat shalat, uang tunai 2.000 riyal, satu set perhiasan emas, berlian dibayar tunai dengan ijab yang diucapkan oleh wali tersebut dan qobul diucapkan oleh laki-laki bernama Drs. Moerdiono.
Secara metodologis, perumusan putusan MK Nomor 46/PUU-VIII/2010 dapat dilihat dari sumber hukum yang menjadi dasar pertimbangan hukum (norma agama dan norma hukum) sebagai berikut: (a) Pencerminan norma agama dalam putusan MK terlihat ketika mayoritas Hakim MK tidak mengakumulasi secara absolut pasal 2 ayat (2); (b) Pencerminan norma hukum yang jauh lebih progresif terlihat ketika putusan MK mengakomodir prinsip-prinsip HAM.

Diakui ataupun tidak, lahirnya putusan MK atas permohonan uji materiil (judical review) yang diajukan Machicha Mochtar dan Muhammad Iqbal Ramadhan bin Moerdiono telah membawa paradigma baru dalam sistem hukum perdata dan hukum keluarga yang berlaku di Indonesia. Berbagai pendapat pro dan kontra mengiringi lahirnya putusan tersebut. Sebagian pendapat menyatakan bahwa putusan itu akan memberikan perubahan hukum ke arah yang lebih baik dalam upaya perlindungan hak-hak anak di mata hukum dan masyarakat, sedang yang lain berpendapat bahwa putusan tersebut akan memunculkan banyak kerumitan dan persoalan baru menyangkut hukum waris yang berlaku di Indonesia, bahkan sebagian aliran keras menyatakan bahwa putusan MK tersebut telah melegalisasi perzinahan di Indonesia.

Mahfud MD sebagai ketua mahkamah konstitusi menyatakan justru putusan ini menghindari perzinahan. Sekarang banyak lakilaki sembarangan menggauli orang, gampang punya simpanan, kawin kontrak terbiasa dengan mudah, yang mana berujung pada perilaku tidak bertanggung jawab dan akhirnya merugikan perempuan dengan meninggalkan anak yang dibebankan kepada ibunya. Putusan MK, justru akan membuat takut para pria yang tidak bertanggung jawab, mengingat putusan MK bahwa anak tidak hanya dibebankan pada ibu, tetapi juga ayah biologisnya.

Mempertautkan antara status perkawinan dengan status anak yang dilahirkan merupakan suatu yang lumrah, hal itu dimaksudkan untuk memberi arti yang penting pada sebuah perkawinan, sehingga pandangan sekularisme dan hedonisme yang menganggap bahwa perkawinan hanya sebatas prosesi ceremonial, tidak tumbuh berkembang di masyarakat Indonesia. Namun, sisi lain hukum juga tidak 
Atik Abidah, Persamaan Derajad Terhadap Pembagian... | 185

boleh menempatkan anak dalam posisi yang rentan ketika terjadi persoalan dengan keabsahan perkawinan orang tuanya. Karena hal tersebut akan menimbulkan persoalan baru terhadap kelangsungan masa depan bangsa.

Secara prinsip tidak boleh mengubah pandangan bahwa setiap hubungan seksual harus didahului oleh sebuah perkawinan yang sah menurut agama dan memenuhi perintah negara, namun terhadap kasus-kasus yang terlanjur lahir anak-anak dari hubungan yang tidak sah, maka hukum juga tidak boleh menutup mata terhadap kenyataan tersebut. Bukanlah sebuah solusi yang tepat jika anakanak itu menjadi objek penelantaran dengan adanya status dan pengakuan secara hukum. Pemberian hak-hak keperdataan bagi si anak tidak akan menjadikan hubungan yang dilakukan orang tuanya sah di mata hukum.

\section{Pergeseran asas persamaan derajat hak anak terhadap pembagian hak waris anak}

Sebagaimana manusia pada umumnya, anak juga memiliki hak asasi manusia (HAM). Sesuai pasal 1 deklarasi universal hak asasi manusia (DUHAM), bahwa semua manusia dilahirkan merdeka mempunyai martabat dan hak yang sama. Lalu pasal 6 yang menyatakan bahwa setiap orang berhak atas pengakuan di depan hukum sebagai manusia secara pribadi di mana saja ia berada. ${ }^{40}$

Perkembangan wacana global tentang HAM memberikan penilaian tersendiri bagi posisi Islam. Berkaitan dengan persamaan derajat terhadap hak anak, agama Islam memposisikan anak sebagai amanah Allah SWT dan tidak bisa dianggap sebagai harta benda yang bisa diperlakukan sekehendak hati oleh orang tuanya. Sebagai amanah anak harus dijaga sebaik mungkin oleh orang tua yang mengasuhnya. Berdasarkan konvensi hak-hak anak, ${ }^{41}$ secara umum hak-hak anak meliputi;

\footnotetext{
${ }^{40}$ Instrumen tentang HAM ini juga terdapat oada pasal 16 Kovenan Internasional tentang hak-hak sipil dan politik, dalam deklarasi Amerika tentang hak dan tanggung jawab manusia baik konvensi Amerika dan Piagam Afrika. Lihat instrumen Internasional Hak Asazi Manusia, (Jakarta: Yayasan Obor Indonesia, 2006), hlm. 95.

${ }^{41}$ Mohammad Joni dan Zu'chaina Z. Tanamas, Aspek Hukum Perlindungan Anak dalam Perspektif Konvensi Hak Anak, (Bandung: Citra Aditya Bakti, 1999), hlm. 35.
}

hak untuk kelangsungan hidup (the right to survival); hak terhadap perlindungan (protection rights); hak untuk tumbuh kembang (development rights); hak untuk berpartisipasi (participation right).

Beranjak dari tujuan pokok hukum Islam (maqashid al-syari'ah), perlindungan hak anak berawal dari urgensi perlindungan hukum Islam terhadap hak-hak anak, baik hak materiil (hak nafkah dan hak waris) maupun hak immateriil (hak pemeliharaan, pembimbingan dan hak perwalian atau pengakuan nasab).

Ditinjau dari aspek materill anak, hukum seyogyanya melindungi kepentingan hak nafkah dan hak waris anak, dengan beberapa alasan: (1) Hak nafkah dan hak waris bagi seorang anak merupakan kebutuhan daruriyyat (kebutuhan primer) yang wajib diberikan kepada seorang anak; (2) Hak nafkah dan hak waris merupakan instrumen hukum yang dibentuk sebagai kelanjutan produktifitas materi yang berpindah dari orang tua kepada anak biologisnya (hifdzu al-mal).

Selanjutnya, terhadap hak immateriil anak, penerapan perlindungan tersebut yaitu dengan menempatkan posisi anak biologis tetap mendapatkan hak pemeliharaan dan pewalian (bagi anak perempuan) dari ayah biologisnya. Pentingnya dua instrumen perlindungan tersebut adalah dengan menormatifkan status ayah dan status anak biologis sebagai hubungan nature yang bersifat bawaan (sunnatullah). Agar supaya ayah biologis tetap bertanggungjawab dalam membangun psikologis anak dalam kehidupan sosial dan ekonomi. Sementara, pentingnya perwalian akan mengatur pada nasab yang memicu kerawanan dalam hal keturunan.

Penegasan hukum Islam untuk melindungi hak-hak anak di atas, berdasarkan pada prinsip bahwa perlindungan hak anak tercermin dalam penjaminan atas penjagaan terhadap jiwa ( $h i f d z$ al-nafs) melalui hak materiil dan keturunan (hifdz al-nasl) melalui hak immateriil anak pada level maslahat daruriyyat wajib diutamakan dari pada menjaga kehormatan (hifdz al-'ird) pada level maslahat tahsiniyyat yang selama ini berkembang di masyarakat.

Persoalan sosial yang meliputi status anak luar kawin sesungguhnya dapat dieliminasi jika sistim hukum lebih memberikan ruang kepada pihak-pihak yang berkepentingan, termasuk 
anak dan ibunya untuk bisa memperjuangkan status dan kedudukan si anak di mata hukum dan masyarakat pada umumnya.

Putusan MK yang melegitimasi perkawinan sah secara agama yang tidak dicatat adalah sah secara hukum positif, merupakan putusan hukum yang sangat progresif dan berani di tengah-tengah gencarnya perdebatan tentang hukum perkawinan sirri dan merevaknya anak hasil "kumpul kebo". Produk hukum yang dibangun merupakan terobosan radikal yang menjadi temuan hukum baru dalam perkembangan hukum di Indonesia. Secara rinci penemuan hukum tersebut berdasarkan pada: (1) Spirit utama yang menjadi pertimbangan hukum bahwa anak adalah amanat dan karunia Tuhan YME yang sama dan sederajat dihadapan siapa, apapun dan kapanpun juga; (2) Hak anak merupakan hak dasar yang diakui oleh sumber hukum manapun, baik norma hukum, adat, terlebih norma agama; (3) Penentuan hak anak atas hak-hak perdata kepada orang tua biologis baik hak materiil maupun hak immaterial tidak dapat dibuktikan hanya dengan mengacu pada paradigma mainstream, yang mengakui hak anak berdasarkan nasab anak atas perkawinan yang sah secara yuridis, tetapi harus dibuktikan melalui hubungan hak dan kewajiban atas nasab biologis yang terbukti memiliki hubungan darah.

Tiga pertimbangan hukum itulah yang menjadi ratio legis ('illat al-hukm) untuk menentukan nasab seseorang kepada orang tuanya. Seperti itulah aplikasi prinsip-prinsip hukum Islam di masyarakat yang koheren dengan perubahan hukum sesuai situasi dan kondisi dalam masyarakat itu sendiri. Mengacu pada teori perubahan hukum, putusan MK tersebut adalah sesuai dengan konteks zamannya, sehingga dapar diterima dalam kehidupan modern sepanjang substansi kebenarannya dapat mewujudkan sebuah hukum itu sendiri, yaitu mewujudkan keadilan dan kemaslahatan bagi masyarakat yaitu anak dari perkawinan yang tidak dicatat.

\section{Analisis terhadap konsep pembuktian hak waris anak berbasis Nasab biologis}

Pembuktian merupakan suatu hal yang tidak bisa ditinggalkan dan sangat menentukan untuk menemukan kebenaran yang sedang dicari oleh hakim. Kaitannya terhadap konsep pembuktian hak waris anak berbasis nasab biologis ini adalah mengedepankan bahwa penetapan nasab melalui pembuktian jelas lebih kuar dari jalan pengakuan, karena bukti adalah merupakan dalil yang paling mendekati kebenaran.

Undang-Undang Nomor 1 tahun 1974 tidak menjelaskan rinci mengenai penetapan nasab melalui cara pembuktian. ${ }^{42}$ Dalam masyarakat modern mengenal adanya alat bukti seperti adanya tes DNA. Upaya dengan tes DNA ini menjadi sangat efektif untuk mengungkap pembuktian dalam hal kasus pidama atau perdata.

Penggunaan alat bukti tersebut merupakan sesuatu yang baru dalam perkara pembuktian adanya hubungan nasab dalam hukum Islam. Pemanfaatan teknologi tersebut adalah sebagai alat bukti sesuai dengan asas dan prinsip hukum yaitu, meniadakan kesempatan dan kesukaran sebagaiman Q.S. Al-Hajj ayat 78, bahwa Allah sama sekali tidak menurunkan agama kepada manusia dengan sesuatu kesempitan.

\section{Akibat Hukum Putusan Mahkamah Konstitusi Nomor 46/PUU-VIII/2010 tenhadap kedudukan anak biologis}

Berdasarkan putusan MK Nomor 46/PUUVIII/2010 bahwa pasal 43 ayat (1) UndangUndang Nomor 1 tahun 1974 tentang perkawinan yang menyatakan: "Anak yang dilahirkan di luar perkawinan hanya mempunyai hubungan perdata dengan ibunya dan keluarga ibunya," dinyatakan bertentangan dengan Undang-Undang Dasar Tahun 1945 sepanjang dimaknai menghilangkan hubungan perdata dengan laki-laki yang dapat dibuktikan berdasarkan ilmu pengetahuan dan teknologi dan/atau alat bukti lain menurut hukum ternyata mempunyai hubungan dara sebagai ayahnya. Sehingga ayat tersebut harus dibaca "anak yang dilahirkan di luar perkawinan mempunyai hubungan perdata dengan ibunya dan keluarga ibunya serta dengan laki-laki

\footnotetext{
${ }^{42}$ Di sana hanya dijelaskan bahwa asal usul seorang hanya dibuktikan dengan adanya akta kelahiran yang otentik, dari pejabat berwnang. Hanya saja ketika akta tidak ditemukan, maka pengadilan sapat menetapkan status anak itu dengan terlebih dahulu diadakan pemeriksaan berdasarkan bukti-bukti yang memenuhi syarat.
} 
sebagai ayahnya yang dapat dibuktikan berdasarkan ilmu pengetahuan dan teknologi dan/atau alat bukti lain menuruy hukum mempunyai hubungan darah, termasuk hubungan perdata dengan keluarga ayahnya".

Menurut hukum Islam seorang anak yang dapat dihubungkan dengan nasab orang tuanya harus memnuhi tiga aspek secara kumulatif, yaitu anak tersebut dilahirkan dalam ikatan perkawinan yang sah, bukan hasil hubungan badan di luar ikatan perwinan (zina), suami istri telah melakukan hubungan badan secara nyata dan anak tersebut dalam kandungan ibunya minimal 6 bulan. Sehingga akibat hukum atas putusan MK tersebut mengarah pada akibat hukum terhadap hak-hak materiil anak yang mencakup; hak kewarisan dan hak atas nafkah. Sedangjan secara immateriil mencakup hak perwalian dan hak alimentasi atau hak hadhanah.

\section{Kesimpulan}

Temuan dari analisis perumusan masalah pertama, perluasan penafsiran konsep nasab anak yuridis kepada anak biologis sehingga pemenuhan hak anak luar perkawinan berdasarkan putusan MK Nomor 46/PUUVIII/2010 mutlak diperlukan sesuai konsep $n a s a b$ biologis sebagai bentuk "PENGAKUAN TERBALIK". Konsep nasab biologis telah memperkuat konsep tabanni yaitu pengakuan dari ayah biologis kepada anak biologis. Pemenuhan hak waris anak dalam putusan MK tersebut melalui pergeseran asas persamaan derajat sesuai dan telah mewujudkan rasa keadilan. Hal ini berdasarkan argumentasi penemuan hukum sebagai berikut: (a) Pemenuhan hak waris anak sangat bermanfaat bagi perlindungan hak-hak perdata anak terutama dalam menjamin keselamatan jiwa anak, menjamin keberlangsungan generasi manusia dan kemaslahatan umum (para pihak, termasuk mencegah kerawanan dalam sistim nasab); (b) Pemenuhan hak waris anak selaras dengan konteks zaman saat ini yang menjadikan ilmu pengetahuan dan teknologi sebagai ratio legis putusan; (c) Diskriminasi terhadap hak waris anak berdasarkan teks agama sungguh tidak berdasar, sebab tidak ada satu teks dan literatur pun yang menyatakan bahwa salah satu penghalang mewarisi adalah karena status anak tidak sah; (d) Diskriminasi terhadap hak waris anak berdasarkan teks agama dan social-setting masa lalu selalu menisbatkan anak dalam sistim patrinial sehingga pengakuan ayah biologis lebih dominan, hasab pada masa lalu sebagai legitimasi hukum bangsa Arab untuk meyakinkan Raja-Raja dan pencitraan ayah biologis, nasab tak lebih sebagai identitas image, tanpa menghiraukan hak-hak anak dan hak-hak perempuan (isteri), serta pada saat yang sama memang belum ada teknologi yang memadai untuk menetapkan secara hukum kedudukan anak. Oleh sebab itu, purifikasi hak-hak perdata anak dan kewajiban-kewajiban ayah biologis mutlak diperlukan; (e) Pemenuhan hak waris dalam pertimbangan dan penalaran hukum hakim, telah memenuhi hukum acara dan melewati rumusan metodologis yang sungguh luar biasa. Pertama, hakim MK menggunakan dua sumber hukum yaitu norma primer berupa pengakuan norma agama dan nilai-nilai HAM sebagai bahan pertimbangan utama, dan norma skunder berupa aturan formal tentang hak waris; kedua, metode riset yang dikembangkan hakim memenuhi syarat-syarat sebuah metode pembaharuan hukum yang menempatkan keadilan dan kebenaran substantif di atas segala-galanya. Teknis riset yang dibangun yaitu dengan mengembangkan dan menggabungkan teks-teks agama berbasis perlindungan HAM (anak) melalui dua teknik yaitu teknik penggalian hukum berdasarkan ayat-ayat qauliyah (Al-Qur'an dan Hadits) yang dipadukan dengan ayat-ayat qauniyah (ilmu hukum, ilmu genetika, tes DNA).

Temuan hasil analisis rumusan masalah kedua, perluasan penafsiram alat bukti "ilmu pengetahuan dan teknologi (tes DNA/RNA)" dalam putusan MK Nomor 46/PUU-VIII/2010 terhadap anak biologis menyebabkan terjadinya pergeseran asas persamaan derajat anak. Akibat hukum pergeseran asas persamaan derajat hak waris anak luar kawin, pertama, merekonstruksi prinsip hak-hak perdata anak baik materiil yaitu nafkah dan hak waris, maupun immaterial yaitu hak perwalian dan hak alimentasi sebagaimana anak sah pada umumnya. Kedua, merekonstruksi hukum acara perdata terutama di bidang hukum pembuktian (IPTEK sebagai bukti). Hal ini berdasarkan argumentasi hukum sebagai 
berikut: (a) Konsep hubungan darah (nasab biologis) merupakan sunnatullah (natural of law) yang bersifat permanen. Sehingga konsep nasab biologis merupakan ratio legis ('illat alhukm) yang menjadi pertimbangan de facto hak-hak perdata anak; (b) Pergeseran hukum hak-hak perdata dari berbasis nasab yuridis (de jure) ke nasab biologis telah mendekonstruksi hak-hak perdata anak berbasis nasab yuridis,

\section{DAFTAR RUJUKAN}

Undang-Undang Nomor 24 tahun 2003 tentang Mahkamah Konstitusi

Manan, Abdul. Aneka Masalah Hukum Perdata Islam di Indonesia. Jakarta: Kencana Prenada Media Group. 2008

Wignyosubroto, Soetandyo. Sebuah Pengantar ke Arah Perbincangan tentang Pembinaan Penelitian Hukum dalam Pembangunan Jangka Panjang Tahap II. Jakarta: BPHN Departemen Kehakiman. 1995

Waluyo, Bambang. Penelitian Hukum dalam Praktek. Jakarta: Sinar Grafika. 2002)

Marzuki, Peter Mahmud. Penelitian hukum. Jakarta: Kencana. 2006

Putusan Mahkamah Konstitusi RI Nomor 46/PUU-VIII/2010

Undang-Undang Nomor 1 Tahun 1974 tentang Perkawinan

Instruksi Presiden Nomor 1 Tahun 1991 tentang Kompilasi Hukum Islam.

Bagus, Lorens. Kamus Filsafat. Jakarta: Gramedia Pustaka Utama. 2000

Asnawi. Teori Maslahah dan Relevansinya dengan Perundang-Undangan Pidana Khusus di Indonesia. Jakarta: Badan Litbang dan Diklat Kemenag RI. 2010

Al-Ghazali, Abu Hamid Muhammad bin Muhammad. Al-Mustasyfa min Ilmi alUshul, Tahqiq wa Tahliq Muhammad Sulaiman al-Asyqar. Juz I. Beirut: Mu'assasat al-Risalah. 1997

al-Qarafy, Shihab al-Din. Syarah Tanqih alFushul fi Ihtisar al-Mahsul fi Usul. Mesir: Maktabah al-Khairiyah. T.th

Praja, Juhaya S. Teori-Teori Hukum, Suatu Telaah Perbandingan dengan Pendekatan Filsafat. Bandung: Pustaka Setia. 2009

Gibb, H.A.R. The Modern Trends of Islam. Jakarta: CV. Rajawali Press. 1991 sehingga hak-hak perdata anak (baik hak materiil maupun hak immateriil) yang tidak diakui, kini diakui secara de jure dan de facto; (c) Konsep pembangunan hukum perdata anak secara radikal berbasis revolusi hukum dalam pengakuan hak-hak perdata anak mutlak diperlukan dalam menjamin hak-hak anak berbasis prinsip-prinsip konstruksi hukum yang Islami.

Al-Jauziyyah, Ibnu Qayyim. I'lam alMuwaqi'in 'an Rabb al-'Alamin. Juz. III. Beirut: Dar al-Jiil. 1973

Djamil, Fathurrahman. Metode Ijtihad Majlis tarjih Muhammadiyah Cet. I. Jakarta: Logos Publishing House 1995

Kurniati, Pemikiran Ibnu Qayyim AlZauziyyah tentang Pengaruh Perubahan Sosial, Jurnal Al-Risalah, Volume 10: 2010

Al-Jauziyyah, Ibnu Qayyim. I'lam alMuwaqi'in Vol. III. Kairo: Maktabat alKulliyyat al-Azhariyyah. 1980

Usman, Mukhlis. Kaidah-Kaidah Ushuliyah dan Fiqhiyyah. Jakarta: Gema Insani Press, 2000

Hamidi, Jazim. Hermeneutika Hukum: Sejarah Filsafat dan Metode Tafsir. Malang: UB Press. 2011

Kiswati, Tsuroyah. Rekonstruksi Metodologis Wacana Keagamaan Muhammad Syahrour, Jurnal Islamica, Volume 4, Nomor 2: 2010,

Masruni, Lauddin. Hukum dan Kebijakan Perpajakan di Indonesia. Yogyakarta: UII Press. 2006

Mulyadi, Lilik. Teori Hukum Pembangunan Prof. Dr. Mochtar Kusumaatmadja, S.H., LL.M, sebuah kajian deskriptif analisis (Online) (diakses di www.hukumonline.com, tanggal 16 februari 2012)

Kusumaatmadja, Mochtar. Fungsi Hukum dalam Pembangunan,. Jakarta: Bina Cipta. 1976

Jurnal Konstitusi oleh Pusat Studi Konstitusi FH Andalas, Perkembangan Pengujian Perundang-undangan di Mahkamah Konstitusi, Jurnal Konstitusi, Volume 7 Nomor 6: 2010 
Atik Abidah, Persamaan Derajad Terhadap Pembagian... | 189

Manan, Munafrizal. Penemuan Hukum oleh Mahkamah Konstitusi. Bandung: Mandar Maju. 2012

Merini, Tinjauan yuridis terhadap kedudukan anak di luar perkawinan pasca putusan MK Nomor 46/PUU-VIII/2010," Palangkaraya: STIH Palangka Raya. 2012
Instrumen Internasional Hak Asazi Manusia. Jakarta: Yayasan Obor Indonesia. 2006 Joni, Mohammad dan Tanamas, Zu'chaina Z . Aspek Hukum Perlindungan Anak dalam Perspektif Konvensi Hak Anak. Bandung: Citra Aditya Bakti. 1999 